\title{
Sugarcane trash chopper cum spreader-A viable machine to avoid trash burning
}

\author{
Anil Kumar*, Nadeem Ahmed Malik, S. Mukesh, Vijaya Rani and Nitin Kadwasra \\ Department of Farm Machinery and Power Engineering C.C.S. Haryana Agricultural University, Hisar-125004 \\ (Haryana), INDIA \\ *Corresponding author. E-mail: anil_saroha@rediffmail.com
}

Received: July 8, 2015; Revised received: February 2, 2016; Accepted: June 8, 2016

\begin{abstract}
Trash burning is a major problem in sugarcane to overcome this, a sugarcane trash chopper cum spreader was tested at farmer's field for its performance and economic feasibility. The chopper cum spreader was tested at five levels of moisture content of trash $(13.2,14,15.15,16.6$, and $18.8 \% \mathrm{db}$ ) and five levels of operational speed $(2.6,2.8,2.9,3.1$, and $3.4 \mathrm{~km} / \mathrm{h})$. The performance of the sugarcane trash chopper cum spreader heavily depends on moisture content and speed of operation. The maximum field capacity $(0.43 \mathrm{ha} / \mathrm{h})$ was obtained at a speed of $3.2 \mathrm{~km} / \mathrm{h}$, but maximum shredding efficiency $(90.40 \%)$ was found at a speed of $2.9 \mathrm{~km} / \mathrm{h}$. Maximum uniformity coefficient $(0.95)$ and shredding capacity $(4.31 \mathrm{t} / \mathrm{h}$ ) was obtained at a speed of $2.9 \mathrm{~km} / \mathrm{h}$ and at a moisture content of $13.13 \%$. Maximum trash lifting efficiency (93.95\%) was observed at a speed of $2.76 \mathrm{~km} / \mathrm{h}$ and at a moisture content of $13.13 \%$. The cost of operation was Rs. $2015 /$ ha with B: C ratio of 1.5 . The break-even point of the chopper cum spreader was $17.7 \mathrm{ha}$ and payback of the machine was 1.3 years if operated for $250 \mathrm{~h} /$ year. The energy consumption of machine was calculated to be $1327.7 \mathrm{MJ} \mathrm{ha}^{-1}$. The optimum performance of sugarcane trash chopper cum spreader was obtained at a moisture content of $13.13 \%\left(\mathrm{M}_{5}\right)$ and forward speed of $2.9 \mathrm{~km} \mathrm{~h}^{-1}\left(\mathrm{~V}_{3}\right)$. The sugarcane trash chopper cum spreader may be recommended for chopping of sugarcane trash for mulching to avoid burning of trash and conserving natural resources.
\end{abstract}

Keywords: Field capacity, Shredding capacity, Shredding efficiency, Uniformity coefficient.

\section{INTRODUCTION}

In India, sugarcane is an important commercial crop occupying about 5.06 million hectares area with an annual production of 335 million tonnes and productivity of $66 \mathrm{t} \mathrm{ha}^{-1}$ during 2012-13, which is very low as compared to world average of $80 \mathrm{t} \mathrm{ha}^{-1}$. Sugarcane occupies about 3.0 per cent of the total cultivated area and it is one of the most important cash crops, contributing about 7.5 per cent of the gross value of agricultural production in the country (Anonymous, 2015).

In sugarcane cultivation, disposal of trash in the field after harvesting of sugarcane is a major problem faced by sugarcane growers in India. In conventional method, after harvesting, dried and semi dried cane trash is collected and heaped or spread in the field. The trash is then usually burnt in the field with the belief that the heat generated, probably eradicates disease causing pathogens and the nutrients of trash are added to the soil in the form of ash. Burning removes the natural trash mulch from the field (Brain and Kenith, 1973). However, trash mulching has proved advantageous in conserving soil moisture, soil protection (against erosion and nutrient leaching), controlling the weeds and specially increasing organic matter and nitrogen fixation by soil micro-organisms (Patriquin,
1982). There are significant quantities of nutrients in fresh cane trash. A typical trash blanket from a $100 \mathrm{t}$ $\mathrm{ha}^{-1}$ crop will contain (approximately) $64 \mathrm{~kg} \mathrm{~N}, 66 \mathrm{~kg}$ $\mathrm{K}, 40 \mathrm{~kg} \mathrm{Ca}, 25 \mathrm{~kg} \mathrm{Mg}, 10 \mathrm{~kg} \mathrm{P}$ and $10 \mathrm{Kg} \mathrm{S}$ (Oliveira et al. 2002, Mitchell and Larsen, 2000). A substantial proportion of these nutrients are lost if the trash is burnt. Moreover, mulch retention can improve soil organic matter and microbial activity (Graham et al. 2005, Yadav et al. 1994). With the retention of trash we can get $30 \% \mathrm{~K}, 23 \% \mathrm{~N}, 18 \% \mathrm{~S}, 17 \% \mathrm{Mg}$ and $11 \%$ $\mathrm{Ca}$ in the field (Mitchell et al., 2000). Mulching of sugarcane trash also showed positive and significant impact on cane yield and sugar recovery (Minhas et al., 2010) and incorporation of residue also shows higher stalk population, higher cane yield and higher sugar yield (Kennedy and Arceneaux, 2006).

In addition to huge loss of plant nutrients, organic matter and degradation of soil properties, burning causes severe air pollution with very bad effects on human and animal health. It has been estimated that one $\mathrm{kg}$ of sugarcane trash on burning release $1,303 \pm 218 \mathrm{~g} \mathrm{CO}$, $65 \pm 14 \mathrm{~g}$ CO $1.5 \pm 0.4 \mathrm{~g} \mathrm{NO}_{\mathrm{x}} 16 \pm 6 \mathrm{~g} \mathrm{UHC}$ and 0.9283g MCE (Franca et al. 2012). This can affect regional environment which also has linkage with global climate change.Possible alternates to avoid trash burning may be treating trash with a chemical adjuvant 
Table 1. Specification of sugarcane trash chopper cum spreader.

\begin{tabular}{lll}
\hline S.N. & Particulars & Values \\
\hline 1. & Dia. of suction fan, mm & 1650 \\
2. & No. of wings & 04 \\
3. & $\begin{array}{l}\text { Ground clearance of } \\
\text { wings, mm }\end{array}$ & 385 \\
4. & RPM of suction fan & 486 \\
5. & RPM of blower fan & 1728 \\
6. & No. of fins & 06 \\
7. & Dia. of fan, mm & 695 \\
8. & No. of blade on each bar & 13 and14 alterna- \\
& & tively on each bar \\
9. & Spacing between blade to & 83 \\
& blade, mm & \\
10. & Dia. of shredder rotor, mm & 719 \\
11. & RPM of shredder rotor & 1188 \\
12. & Power required, HP & $45-60$ \\
\hline
\end{tabular}

for decomposition, reducing the residue particle size by shredding and then incorporating the trash in the soil or to retain it on the surface. Keeping in view of the above a prototype of sugarcane trash chopper cum spreader was evaluated and tested for its performance and economic feasibility.

\section{MATERIALS AND METHODS}

A sugarcane trash chopper cum spreader whose specifications were given below was tested at farmers field in Bharpur village of Ratia Tehsil of Fatehabad district in Haryana state, whereas laboratory testing of machine and crop parameters were done in the laboratory of department of Farm Machinery and Power Engineering, CCS Haryana Agricultural University, Hisar, Haryana during 2012-13.

Treatments: The sugarcane trash chopper cum spreader was tested at five different forward speeds $\mathrm{V}_{1}$ $\left(2.76 \mathrm{~km} \mathrm{~h}^{-1}\right), \mathrm{V}_{2}\left(2.8 \mathrm{~km} \mathrm{~h}^{-1}\right), \mathrm{V}_{3}\left(2.9 \mathrm{~km} \mathrm{~h}^{-1}\right), \mathrm{V}_{4}$ $\left(3.12 \mathrm{~km} \mathrm{~h}^{-1}\right), \mathrm{V}_{5}\left(3.2 \mathrm{~km} \mathrm{~h}^{-1}\right)$ and at five different moisture contents $\mathrm{M}_{1}(18.75 \%), \mathrm{M}_{2}(16.54 \%), \mathrm{M}_{3}$ $(15.15 \%), \mathrm{M}_{4}(13.19 \%), \mathrm{M}_{5}(13.15 \%)$ on dry basis with three replication.

Field and crop parameters: The machine was tested in high yielding mid maturing sugarcane variety $\mathrm{CoH}$ 119. The various crop parameters as dimensions of the sugarcane trash like length $(\mathrm{cm})$, thickness $(\mathrm{cm})$ of stalk, amount of trash left on the ground $\left(\mathrm{t} \mathrm{ha}^{-1}\right)$, moisture content of trash and soil $(\% \mathrm{db})$, row to row and plant to plant spacing $(\mathrm{cm})$ and density of trash $\left(\mathrm{g} \mathrm{cm}^{-}\right.$ ${ }^{3}$ ) were determined from randomly selected samples before and after operation of the sugarcane chopper cum spreader.

Performance parameters: The various performance parameters which were calculated during the field test were as follows:

Field capacity $\left(h a h^{-1}\right)$

$\mathrm{Es}=$ " $\mathrm{T}$

Where, Es = Field capacity of the machine, ha $\mathrm{h}^{-1}$

$\mathrm{A}=$ Total area covered, ha

$\mathrm{T}=$ Time of operation, $\mathrm{h}$

Field efficiency $(\%)$

$\mathrm{e}_{=}^{\frac{E_{\mathbf{g}}}{E_{\mathrm{i}}}} \times 100$

Where, e = Field efficiency, $\%$

$\mathrm{E}_{\mathrm{t}}=$ Theoretical field capacity,

Es $=$ Actual field capacity,

$\mathrm{E}_{\mathrm{t}}=$ Width $\mathrm{x}$ Speed $\left(\mathrm{kmh}^{-1}\right)$

Shredding efficiency $(\%)$

$\mathrm{E}_{\mathrm{c}}=\frac{\mathrm{F}}{\mathrm{C}} \times 100$

Where, $\mathrm{E}_{\mathrm{c}}=$ Shredding efficiency of the machine, $\%$

$\mathrm{F}=$ Amount of chopped trash on the field after operation, $\mathrm{t} \mathrm{ha}^{-1}$

$\mathrm{C}=$ Amount of trash on the field before operation, tha $^{-1}$

Trash size reduction (\%)

$\mathrm{E}_{\mathrm{b}}=\frac{\mathrm{F}}{\mathrm{B}} \times 100$

Where, $\mathrm{E}_{\mathrm{b}}=$ Trash size reduction, per cent

$\mathrm{F}=$ Length of trash after operation, $\mathrm{cm}$

$\mathrm{B}=$ Length of trash before operation, $\mathrm{cm}$

Shredding capacity $\left(\mathbf{t ~ h}^{-1}\right)$

$\mathrm{Sc}=\mathrm{A}_{\mathrm{T}} \times$ Field capacity, ha $\mathrm{h}^{-1}$

Where, $\mathrm{Sc}=$ Shredding capacity, $\mathrm{t} \mathrm{h}^{-1}$

$\mathrm{A}_{\mathrm{T}}=$ Amount of trash on field, $\mathrm{tha}^{-1}$

Uniformity coefficient:

$\mathrm{Uc}=\frac{A_{t}}{A_{\mathrm{m}}}$

Where, $A_{t}=$ Amount of trash left on the selected plot, $\mathrm{kg}$

$\mathrm{A}_{\mathrm{m}}=$ Average amount of trash left on all plots, $\mathrm{kg}$

$\mathrm{U}_{\mathrm{c}}=$ Uniformity coefficient

Economics parameters: The economics of tractor

Table 2. Effect of different forward speed on performance parameters of the machine.

\begin{tabular}{|c|c|c|c|c|c|c|}
\hline Treatment & $\begin{array}{c}\text { Average } \\
\text { wheel slip, \% }\end{array}$ & $\begin{array}{l}\text { Fuel consumption, } \\
\qquad \mathbf{h ~ h}^{-1}\end{array}$ & $\begin{array}{l}\text { Av. width of } \\
\text { operation, m }\end{array}$ & $\begin{array}{c}\text { Field capacity, } \\
\text { ha h}^{-1}\end{array}$ & $\begin{array}{l}\text { Field effi- } \\
\text { ciency, \% }\end{array}$ & $\begin{array}{l}\text { Shredding } \\
\text { efficiency, \% }\end{array}$ \\
\hline V1 & 2.90 & 8.78 & 1.78 & 0.36 & 77.30 & 84.0 \\
\hline $\mathrm{V} 2$ & 3.20 & 9.00 & 1.77 & 0.38 & 77.90 & 88.40 \\
\hline V3 & 3.40 & 8.85 & 1.75 & 0.41 & 80.80 & 90.40 \\
\hline V4 & 3.40 & 8.75 & 1.76 & 0.42 & 76.50 & 86.60 \\
\hline V5 & 3.50 & 9.15 & 1.75 & 0.43 & 76.80 & 85.20 \\
\hline Mean & 3.25 & 8.95 & 1.76 & 0.40 & 78.20 & 87.00 \\
\hline C.D. & 0.32 & N.S. & N.S. & N.S. & N.S. & 3.69 \\
\hline $\mathrm{SE}(\mathrm{m})$ & 0.10 & 0.52 & 0.29 & 0.06 & 1.16 & 1.16 \\
\hline
\end{tabular}

Critical difference (C.D.) at $5 \%$ level of significance. 
Table 3. Effect of forward speed and moisture content of trash on shredding capacity $\left(\mathrm{t} \mathrm{h}^{-1}\right)$.

\begin{tabular}{lcccccc}
\hline Treatment & M1 (18.75\%) & M2 (16.54\%) & M3 (15.15\%) & M4 (13.19\%) & M5 (13.13\%) & Mean V \\
\hline V1 & 3.56 & 3.70 & 3.90 & 3.88 & 4.17 & 3.84 \\
V2 & 3.66 & 3.79 & 3.92 & 4.08 & 4.25 & 3.94 \\
V3 & 3.67 & 3.81 & 4.00 & 4.14 & 4.31 & 3.99 \\
V4 & 3.63 & 3.75 & 3.77 & 3.93 & 4.23 & 3.86 \\
V5 & 3.58 & 3.66 & 3.89 & 3.88 & 4.13 & 3.83 \\
Mean M & 3.62 & 3.74 & 3.90 & 3.99 & 4.22 & \\
Factors & & & & & SE (m) & \\
Factor (M) & & & 0.021 & 0.021 & \\
Factor (V) & & & 0.061 & & & \\
\hline
\end{tabular}

Critical difference (C.D.) at $5 \%$ level of significance.

Table 4. Effect of forward speed and moisture content of trash on trash lifting efficiency (\%).

\begin{tabular}{|c|c|c|c|c|c|c|}
\hline Treatment & M1 $(18.75 \%)$ & M2 (16.54 \%) & M3 (15.15 \%) & M4 (13.19\%) & M5 (13.13 \%) & Mean V, \% \\
\hline V1 & 86.29 & 86.4 & 87.54 & 88.08 & 93.95 & 88.45 \\
\hline V2 & 84.90 & 86.58 & 86.98 & 88.26 & 91.86 & 87.72 \\
\hline V3 & 83.96 & 85.63 & 85.67 & 87.27 & 91.03 & 86.71 \\
\hline V4 & 81.14 & 86.15 & 86.71 & 88.18 & 90.87 & 86.61 \\
\hline V5 & 83.15 & 84.87 & 85.80 & 86.73 & 89.34 & 85.98 \\
\hline Mean V & 83.89 & 85.93 & 86.54 & 87.7 & 91.41 & \\
\hline Factors & & \multicolumn{2}{|r|}{ C.D. } & \multicolumn{3}{|c|}{$\mathrm{SE}(\mathrm{m})$} \\
\hline Factor (M) & & \multicolumn{2}{|r|}{1.07} & \multicolumn{3}{|c|}{0.38} \\
\hline Factor $(\mathrm{V})$ & & \multicolumn{2}{|r|}{1.25} & \multicolumn{3}{|c|}{0.44} \\
\hline
\end{tabular}

Critical difference (C.D.) at $5 \%$ level of significance.

operated sugarcane trash chopper cum spreader will be helpful in decision making for purchasing a new machine for individual farmer to own a machine or its custom hiring. In order to determine the technoeconomic feasibility of prototype, four economic parameters i.e. cost of operation, benefit-cost ratio (B:C Ratio), payback period (PBP) and Break-Even point (BEP) were calculated as follows.

Cost of operation $=\frac{F \cdot C+V . C}{H}$

Where, F.C = Total fixed cost, Rs.

V.C $=$ Total variable cost, Rs.

$\mathrm{H}=$ Working hours, $\mathrm{h}$

Break-even point (B.E.P):

$\mathrm{BEP}=\frac{\mathrm{FC}}{\mathrm{CF}-\mathrm{E}}$

Where, BEP = Break even point, ha

$\mathrm{FC}=$ Annual fixed cost, $\square \mathrm{yr}^{-1}$

$\mathrm{CF}=$ Custom hiring fee, $\square \mathrm{h}^{-1}$

$\mathrm{C}=$ Operating cost, $\square \mathrm{h}^{-1}$

Payback period:

$\mathrm{P}=\frac{1}{\mathrm{E}}$

Where, $\mathrm{P}=$ Pay back period, years

$\mathrm{I}=$ Amount of investment, Rs.

$\mathrm{E}=$ Expected annual net revenue, Rs. $\square$

Benefit Cost ratio:

B: C Ratio = Gross return, $\mathrm{Rs} \mathrm{ha}^{-1}$

Cost of operation, $\mathrm{Rs} \mathrm{ha}^{-1}$

Energy requirement: The energy requirement of the sugarcane trash chopper cum spreader was determined by considering energy from all sources such as human, diesel, tractor and machinery during the operation as prescribed by Panesar (2002).

Statistical Analysis: The experimental data recorded were subjected to statistical analysis in accordance with the help of "Analysis of variance" technique. The critical difference (CD) for the treatment comparisons were worked out wherever the variance ratio ( $\mathrm{T}$ test) was found significant at 5 per cent level of probability.

\section{RESULTS AND DISCUSSION}

Effect of forward speed and moisture content of trash on performance parameter: The field capacity of the sugarcane trash chopper cum spreader varies from 0.36 to $0.43 \mathrm{ha} \mathrm{h}^{-1}$ with an average of $0.40 \mathrm{ha} \mathrm{h}^{-1}$ (Table 2). The variation in field capacity was due to increase in forward speed of operation, however, the results were found non significant at $5 \%$ level of significance. The highest field capacity, $0.43 \mathrm{ha} \mathrm{h}^{-1}$ was found at a speed, $\mathrm{V}_{4}\left(3.12 \mathrm{~km} \mathrm{~h}^{-1}\right)$ and minimum field capacity, $0.36 \mathrm{ha} \mathrm{h}^{-1}$ at speed, $\mathrm{V}_{1}\left(2.76 \mathrm{~km} \mathrm{~h}^{-1}\right)$. The similar findings were given by Patil et al. (2009) showing that the field capacity of the sugarcane trash shredder varies from 0.2 to 0.5 ha $\mathrm{h}^{-1}$ in sugarcane crop. The field efficiency of the machine varied with varying forward speeds of operation. The average field efficiency of the machine was found out to be $78.2 \%$. Initially the field efficiency of the machine showed an increasing trend primarily due to lower wheel slip and higher efficiency of suction unit. However, with increase in speed, the wheel slip increases and the efficiency of suction unit decreases thus causing decrease in field efficiency. The results were found non significant at 5\% level of significance. Patil et al. (2009) also 
Table 5. Effect of forward speed and moisture content of trash on uniformity coefficient.

\begin{tabular}{lcccccc}
\hline Treatment & M1 (1 8.75\%) & M2 (16.54\%) & M3 (15.15\%) & M4 (13.19\%) & M5 (13.13\%) & Mean V, \% \\
\hline V1 & 0.90 & 0.92 & 0.91 & 0.91 & 0.92 & 0.91 \\
V2 & 0.92 & 0.92 & 0.93 & 0.92 & 0.92 & 0.92 \\
V3 & 0.94 & 0.94 & 0.93 & 0.94 & 0.95 & 0.94 \\
V4 & 0.94 & 0.93 & 0.94 & 0.94 & 0.93 & 0.94 \\
V5 & 0.93 & 0.93 & 0.93 & 0.94 & 0.94 & 0.93 \\
Mean V & 0.93 & 0.93 & 0.93 & 0.93 & 0.93 & \\
Factors & & & C.D. & & \\
Factor (M) & & & N.S & & \\
Factor (V) & & & & N.S & & \\
\hline
\end{tabular}

evaluated sugarcane trash shreeding machine and found that field capacity varies from $0.28 \mathrm{ha} \mathrm{h}^{-1}$ to 0.62 ha $\mathrm{h}^{-1}$ and field efficiency varies from $51.34 \%$ to $74.01 \%$.. The field efficiency was highest $(80.8 \%)$ at forward speed $\mathrm{V}_{3}\left(2.9 \mathrm{~km} \mathrm{~h}^{-1}\right)$ and lowest $76.5 \%$ at forward speed $\mathrm{V}_{4}\left(3.12 \mathrm{~km} \mathrm{~h}^{-1}\right)$.

The shredding efficiency of machine varies from 84 to $90.4 \%$ with forward speed of 2.76 to $3.2 \mathrm{~km} \mathrm{~h}^{-1}$. The trash shredding showed significant deviation at 5\% level of significance at varying speeds. The percentage of the chopped trash was found highest $90.4 \%$ at speed, $\mathrm{V}_{3}\left(2.9 \mathrm{~km} \mathrm{~h}^{-1}\right)$. The results were found significant at $5 \%$ level of significance. Verula (2010) designed and developed a shredder whose shredding efficiency was found to be $81 \%$.

Effect of forward speed and moisture content of trash on shredding capacity $\left(\mathbf{t ~ h}^{\mathbf{- 1}}\right)$ : The shredding capacity of machine varies from 3.56 to $4.31 \mathrm{t} \mathrm{h}^{-1}$ with forward speed of 2.76 to $3.2 \mathrm{~km} \mathrm{~h}^{-1}$ at a moisture content of 13.13 to $18.75 \%$ (Table 3 ). An inverse relationship was observed between the moisture content of the trash and the shredding capacity. This negative relationship was attributed to the fact that increase in moisture content of the trash results in increase of weight of the trash which results in decreased trash lifting efficiency and thus decreasing shredding capacity. The shredding capacity increased initially with increase in speed of operation and the maximum shredding capacity was obtained at speed of $2.9 \mathrm{~km} \mathrm{~h}^{-1}\left(\mathrm{~V}_{3}\right)$. The shredding capacity decreased with further increase in the speed of operation. The initial increase in the shredding capacity of the machine was due to the fact that the suction unit was not able to lift the maximum trash at lower speed, with increasing speed the trash available to the suction unit increases however after reaching maximum capacity at optimum speed the shredding capacity decreases on further increasing the speed. The reason might be due to lesser time available to the suction unit to lift the whole trash from the field. The maximum shredding capacity of the machine was found to be $4.31 \mathrm{t} \mathrm{h}^{-1}$ at moisture content of $13.13 \%$ $\left(\mathrm{M}_{3}\right)$ and forward speed of $2.9 \mathrm{~km} \mathrm{~h}^{-1}\left(\mathrm{~V}_{3}\right)$. The results were found significant at $5 \%$ level of significance.

Effect of forward speed and moisture content of trash on trash lifting efficiency (\%): The trash lifting efficiency of machine varies from $81.14 \%$ to $93.95 \%$ with forward speed of 2.76 to $3.2 \mathrm{~km} \mathrm{~h}^{-1}$ at a moisture content of 13.13 to $18.75 \%$ (Table 4 ). The trash lifting efficiency of the machine showed a varying trend with the moisture content of the trash and forward speed of operation. Trash lifting efficiency decreases with the increase in moisture content that might be due to increase in weight of the trash at high moisture contents. The trash lifting efficiency showed a linear increasing trend with the increasing forward speed, which can be attributed to the fact that at low forward speed the time required to lift the trash is more as compared to higher forward speed. The maximum trash lifting efficiency of the machine was found to be $93.95 \%$ at moisture content of $13.13 \%\left(\mathrm{M}_{5}\right)$ and forward speed of $2.76 \mathrm{~km}$ $\mathrm{h}^{-1}\left(\mathrm{~V}_{1}\right)$. The results were found significant at $5 \%$ level of significance. Similar findings were found by Aravindareddy et al. (2008) found that increase in speed from 2.4 to $3.0 \mathrm{~km} \mathrm{~h}^{-1}$ resulting in increase in collection efficiency of 96.6 and $96.7 \%$ for 20 and $30 \mathrm{~mm}$ ground clearance, in sugarcane crop.

Effect of forward speed and moisture content of trash on uniformity coefficient: The uniformity coefficient of the machine varies from 0.90 to 0.95 with forward speed of 2.76 to $3.2 \mathrm{~km} \mathrm{~h}^{-1}$ at a moisture content of 13.13 to $18.75 \%$ (Table 5). The maximum uniformity (0.95) was obtained at moisture content of $13.13 \%$ and forward speed of $2.9 \mathrm{~km} \mathrm{~h}^{-1}$, however the results were found non satisfactory.

Economics and Energy parameters: The cost of operation of sugarcane trash chopper cum spreader was Rs. 786/h and Rs. 2015/ha. The benefit cost ratio was found to be 1.5 . The result of $\mathrm{B}$ : $\mathrm{C}$ ratios of more than unity indicate that investment in machine is economically viable. Belonio (2003) developed a low cost axial flow type shredder for grasses, trashes and leaves operated by $7.5 \mathrm{hp}$ gasoline engine with capacity of 0.7 $-1.5 \mathrm{t} /$ day and found a B:C ratio of 2.18. The Pay Back period of the sugarcane trash chopper cum spreader

Table 6. Economical and energy parameters of sugarcane trash chopper cum spreader.

\begin{tabular}{clc}
\hline S. N. & Particulars & Value \\
\hline 1 & Labour requirement, man-h ha $^{-1}$ & 2.5 \\
2 & ${\text { Cost of operation, } \mathrm{Rs} \mathrm{h}^{-1}}^{-1}$ & 786 \\
3 & Cost of operation, Rs ha & 2015 \\
4 & Benefit Cost ratio & 1.5 \\
5 & Pay Back period, years & 1.3 \\
6 & Break Even point, ha. & 17.7 \\
7 & Energy requirement, $\mathrm{MJ} \mathrm{ha}^{-1}$ & 1327.7 \\
\hline
\end{tabular}


was found to be 1.3 years if operated for 250 hours per year. Breakeven point was found to be 17.7 ha, which means that the shredder is feasible for large scale farmers. However custom hiring of the machine can be useful for small farmers for income generation. The energy requirement of the sugarcane trash chopper cum spreader was found to be $1327.7 \mathrm{MJ} / \mathrm{ha}$.

\section{Conclusion}

The performance of the sugarcane trash chopper cum spreader heavily depends on moisture content and speed of operation. The maximum field capacity $(0.43 \mathrm{ha} / \mathrm{h})$ was obtained at a speed of $3.2 \mathrm{~km} / \mathrm{h}$, but maximum shredding efficiency $(90.40 \%)$ was found at a speed of $2.9 \mathrm{~km} / \mathrm{h}$. Maximum uniformity coefficient (0.95) and shredding capacity $(4.31 \mathrm{t} / \mathrm{h})$ was obtained at a speed of $2.9 \mathrm{~km} / \mathrm{h}$ at a moisture content of $13.13 \%$. Maximum trash lifting efficiency $(93.95 \%)$ was observed at a speed of $2.76 \mathrm{~km} / \mathrm{h}$ at a moisture content of $13.13 \%$. Moisture content of mulched soil was 2.5 percent higher than the un-mulched soil after 4 months. The cost of operation was Rs. 2015/ha with B:C ratio of 1.5. The break-even point of the chopper cum spreader was 17.7 ha and payback of the machine was 1.3 years if operated for $250 \mathrm{~h} /$ year. The energy consumption of machine was calculated to be $1327.7 \mathrm{MJ}$ $\mathrm{ha}^{-1}$. The optimum performance of sugarcane trash chopper cum spreader was obtained at a moisture content of $13.13 \%\left(\mathrm{M}_{5}\right)$ and forward speed of $2.9 \mathrm{~km} \mathrm{~h}^{-1}$ $\left(\mathrm{V}_{3}\right)$. The sugarcane trash chopper cum spreader may be recommended for chopping of sugarcane trash for mulching to avoid burning of trash and conserving natural resources.

\section{REFERENCES}

Anonymous. (2015). Web site of department of Agriculture and Co-operation, Ministry of Agriculture, Govt. of India.

Aravindareddy, G., Manian, R. and Kathirvel, K. (2008). Effect of relative of picking tyne, ground clearance, quantity of trash left on collection efficiency of the sugarcane trash collector. Agricultural Mechanization in Asia, Africa and Latin America, 39(3): 72-78.

Belonio, A.T., Lim, A.A., Lete, G.L. and Romallosa, R.D. (2003). Low-cost axial-flow type biomass shredder.
Philippine Agriculture Magazine of the Manila Bulletin 9(5): 55.

Brain, W.E. and Kenneth, C. (1973). Trash mulch and sugarcane yields in Barbados. Proc. of West Indian Sugar Technologists Meeting 5: 147-157.

Franca, D.D.A., Longo, K.M., Neto, T.G.S., Santos, J.C., Freitas, S.R., Rudorff, B.F.T., Cortez, E.V., Anselmo, E. and Jr., J.A.C. (2012). Pre-Harvest Sugarcane Burning: Determination of Emission Factors through Laboratory Measurements. Atmosphere, 3:164-180.

Graham, M.H., Haynes, R.J. and Meyer, J.H. (2005). Soil organic matter content and quality: effects of fertilizer applications, burning and trash retention on long-term sugarcane experiment in South Africa. Soil Biol. Biochem 34: 93-102.

Kennedy, C.W. and Arceneaux, A.E. (2006). Effect of harvest residue management inputs on soil respiration and crop productivity of sugarcane. Journal of American Society of Sugarcane Technologists 26: 125-136.

Minhas, S.Y.J., Baloch, L.M. and Minhas, S. (2010). Effect of trash mulch and $\mathrm{N}$ levels on cane yield and recovery of sugarcane variety Thatta-10. Pakistan Sugar Journal 28(1): 17-22.

Mitchell, R.D.J. and Larsen, P.J. (2000). A simple method for estimating the return of nutrients in sugarcane trash. Proc. Aust. Soc. Sugar Cane Techno 22: 212-216.

Oliveira, D.M.W., Trivelin, P.C.O., Kingston, G., Barbosa, M.H.P. and Vitti, A.C. (2002). Decomposition and release of nutrients from sugarcane trash in two agricultural environments in Brazil. Proc. Aust. Soc. Sugar Cane Technol 24: 290-296.

Panesar, B.S. (2002). Energy norms for input and output for agricultural sector. Faculty trainning program on energy in production agriculture and alternative energy sources, PAU, Ludhiana, March 6-26 2002.

Patil, S.B., Bongane, G.M., Durge, S.N. and Kawale, R.S. (2009). Performance evaluation of sugarcane trash shredding machine with different hp tractors in different gear settings. International Journal of Agricultural Engineering 2(1): 146-148.

Patriquin, D.G. (1982). Nitrogen fixation in sugarcane litter. Biological Agriculture and Horticulture, 1:39-64.

Verula, C.M. (2010). Design and development of shredder for incorporation of green manure. Phillipines Education Research Journal 9 (5): 22-31.

Yadav, R.L., Prasad, S.R., Singh, R. and Srivastava, V.K. (1994). Recycling sugarcane trash to conserve soil organic carbon for sustaining yields of successive ratoon crops in sugarcane. Bio. Technol 49: 231-235. 